\title{
The pH-dependent dissolution of wind-transported Saharan dust
}

\author{
Karine V. Desboeufs, Rémi Losno, Françoise Vimeux, and Sylvain Cholbi \\ Laboratoire Interuniversitaire des Systèmes Atmosphériques, Universités Paris 7 et 12, Créteil, France
}

\begin{abstract}
An open flow reactor was developed and used to study the $\mathrm{pH}$ dependency of atmospheric aerosol weathering. Under ultraclean conditions, this reactor enables experiments below the saturation of hydroxy salts and over the short time span ( 2 hours) that is typical for weathering by rain and cloud water. The weathering simulations show a two-step process of dissolution rates: First, the rate increases quickly during the hydration of the solid particle surface, then after a maximum, it progressively decreases. In general, there is an increase in the dissolution rate of dissolved elements as the $\mathrm{pH}$ is lowered. However, between $\mathrm{pH} 3.80$ and 5.30 , the dissolution rate for $\mathrm{Fe}$ and $\mathrm{Cu}$ depends on both $\mathrm{H}^{+}$and $\mathrm{OH}^{-}$concentrations and exhibits a minimum as a function of $\mathrm{pH}$. This minimum can be related to $\mathrm{pH}_{\mathrm{pzc}}$ of the mineral containing these elements. The affinity of minerals for $\mathrm{H}^{+}$was also determined by correlating hydration constants and $\mathrm{pH}$.
\end{abstract}

\section{Introduction}

Dissolved trace metals are an important key in understanding atmospheric aqueous phase chemistry: For example, they probably control catalytic oxidation of $\mathrm{SO}_{2}$ producing acid precipitation [Hoffmann and Boyces, 1983; Graedel et al., 1985; Berresheim and Jaeschke, 1986; Clarke and Radojevic, 1987]. Trace amounts of transition metals, for example, Fe, $\mathrm{Mn}$, and $\mathrm{Cu}$, readily modify oxidation and reduction paths in droplets [Graedel et al., 1986; Jacob et al., 1989; Faust and Hoigné, 1990, Walcek et al., 1997; Losno, 1999] because they control the concentration of free radicals. These metals are also involved in a number of organic processes that occur in atmospheric droplets, that is, production and destruction of alkyl-hydroperoxides, and chemical chains that link $\mathrm{RO}_{2}$ radicals to stable alcohols and acids and oxidation of aliphatic aldehydes to form organic acids [Weschler et al., 1986].

On a global scale, desert aerosols are the main sources of trace metals to the atmosphere [Lantzy and Mackenzie, 1979; Nriagu and Pacyna, 1988]. Prior to removal by wet or dry deposition processes, aerosol particles are subjected to multiple cycles of wetting and drying during cloud condensation and evaporation [Junge, 1964]. They undergo partial weathering, which causes the solubilization of elements from minerals and metals. This initial leaching process establishes the chemistry of the aqueous solution that will define several subsequent atmospheric chemical processes, for example, mineral dusts from crustal weathering can neutralize acidic precipitation [Khemani et al., 1987; Losno et al., 1991]. This weathering process can modify the solid aerosol surface and so affect the optical and chemical properties [Lowe et al., 1996; Herrmann and Hänel, 1997].

Wet atmospheric deposition is a major source of trace metals and nutrients to the oceans [Patterson and Settle, 1987; Duce et al., 1991]. It has been suggested that Fe [Brand et al., 1983; Martin and Fitzwater, 1988] and Mn [Sunda et al., 1981; De

Copyright 1999 by American Geophysical Union.

Paper number 1999JD900236.

0148-0227/99/1999JD900236\$09.00
Baar et al., 1989] may act as limiting nutrients for phytoplankton growth. Free metals, rather than the total or chelated metal concentrations, control the biological availability [Anderson and Morel, 1982; Rich and Morel, 1990]. This input of trace metals to the oceans may thus influence the global climate via stimulation of dimethyl sulfide production by phytoplankton [Zhuang et al., 1992] or $\mathrm{CO}_{2}$ uptake [Smith and Mackenzie, 1991; Martin et al., 1994].

Despite the obvious importance of solubilization of metals from dust in atmospheric waters, experimental works on this subject are scarce. Experiments simulating the timescales representative of those in cloud and rainwater showed a strong relationship between the dust mineralogy, $\mathrm{pH}$ of the solution and the solubility of transition metals for Saharan aerosol [Spokes et al., 1994], and fuel ash and industry steel dust particles [Williams et al., 1988]. Several studies using natural or artificial rainwater have suggested that the $\mathrm{pH}$ is a major factor controling solubility in rain and snow [Maring and Duce, 1987; Prospero et al., 1987; Losno et al., 1988; Statham and Chester, 1988; Colin et al., 1990; Lim and Jickells, 1990].

In this study, we used a flow-through reactor of the same type that was used previously to simulate terrestrial mineral weathering [Chou and Wollast, 1984; Mast and Drever, 1987; Schnoor, 1990; Bruno et al., 1991]. This reactor enables us to reproduce the rapid kinetic interactions between particulate and aqueous phases in atmospheric water. We discuss here the performance of this reactor when applied to the dissolution of mineral phases in part of conditions encountered in clouds where ionic strength remains low. Despite its importance for solubility history and bioavailability [Zhu et al., 1997; Spokes and Jickells, 1996], in this paper we will not consider evaporation of a cloud droplet when ionic strength becomes very high and $\mathrm{pH}$ is very low. During evaporation, cloud conditions can be compared to the aerosol solution described by $Z h u$ et al. [1992]. In our experiments, we have determined simultaneously the $\mathrm{pH}-$ dependent dissolution of the elements: $\mathrm{Na}, \mathrm{Mg}, \mathrm{Si}, \mathrm{K}, \mathrm{Ca}, \mathrm{Mn}$, $\mathrm{Fe}, \mathrm{Cu}, \mathrm{Sr}$, and $\mathrm{Ba}$ at timescales representative of evaporationcondensation cycles in atmospheric cloud droplets. Our objectives were to identify and quantify the individual steps of mineral aerosols'weathering as they enter into a cloud. 


\section{Materials and Method}

\subsection{Method Used}

The apparatus was designed to prevent equilibration of solid aerosol particles with insoluble salts. We used an open-flow reactor, wherein it was possible to maintain levels of dissolved species concentrations well below the saturation. The initial dissolution of the solids was exclusively studied without interference from secondary precipitation reactions. Evaluations of the effects of various chemical conditions on the dissolution of the introduced samples were possible by changing the composition of the input weathering solution.

\subsection{Description of the Reactor}

This reactor (Figure 1) was designed to work under ultraclean conditions. The dissolution chamber consists of a cylinder, a perforated stand, and a $0.4 \mu \mathrm{m}$ porosity Nuclepore ${ }^{\mathrm{TM}}$ filter. This porosity defines what is soluble and what is not [e.g., Lim and Jickells, 1990]. The pump induces an upward circulation of the weathering solution. The solution containing the dissolved elements is collected at the outlet at regular intervals. A magnetic stirrer maintains a homogeneous suspension in the dissolution chamber. An experimental check of homogeneous mixing was performed.

The dissolution rate is expressed as

where

$$
R=\frac{d n}{d t}=F\left(C_{t}-C_{x}\right)+V \frac{d C}{d t}
$$

C solute concentration at time $\mathrm{t}$ inside the reactor $\left(\mathrm{mol} \mathrm{L}{ }^{-1}\right)$;

$C_{1}$ and $C_{x}$ concentrations of solute in the entering solution and the outgoing solution, respectively $\left(\mathrm{mol} \mathrm{L}^{-1}\right)$;

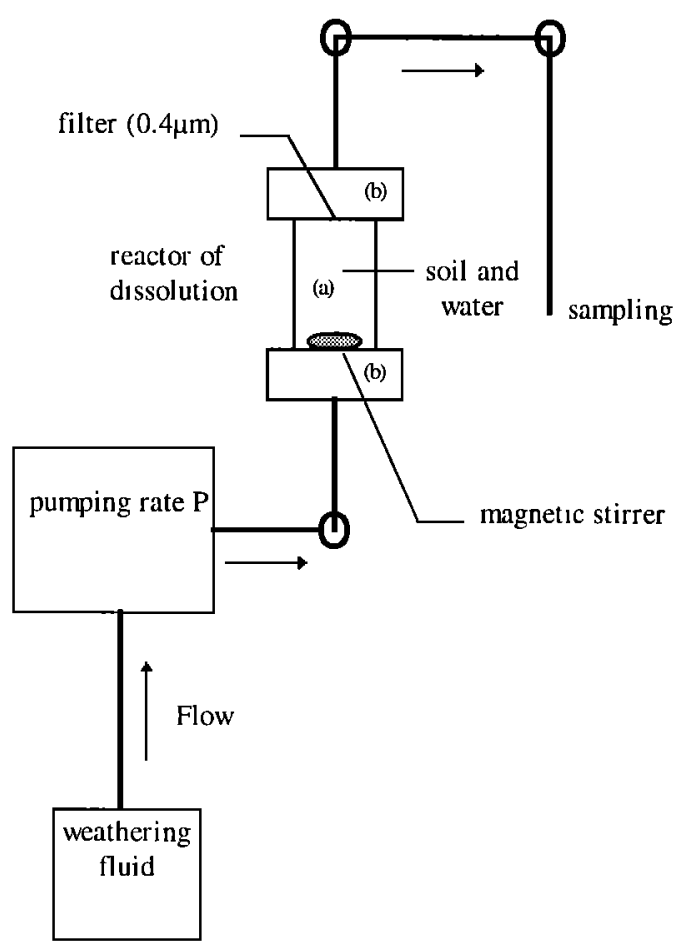

Figure 1. Schematic of dissolution reactor that includes a main body of transparent polycarbonate (labeled a) surrounded by two Teflon ${ }^{\mathrm{TM}}$ pieces (labeled $\mathrm{b}$ ). The lower piece holds a perforated Teflon $^{\mathrm{TM}}$ stand which carries the particulate sample at the beginning of the experiment. The upper piece houses a $0.4 \mu \mathrm{m}$ porosity Nuclepore ${ }^{\mathrm{TM}}$ filter. All tubing and vanes are manufactured from Teflon ${ }^{\mathrm{TM}}$ and connect the chamber to the pump and the sample area.

Table 1a. Percentage of Elements Present in the Loess Sample

\begin{tabular}{cl}
\hline Element & Percentage \\
\hline $\mathrm{S}$ I & $22.7^{*}$ \\
$\mathrm{Al}$ & $8.4^{*}$ \\
$\mathrm{Fe}$ & $7.6^{*}$ \\
$\mathrm{Ca}$ & $3.8^{*}$ \\
$\mathrm{Mg}$ & $28^{*^{+}}$ \\
$\mathrm{K}$ & $1.3^{*^{+}}$ \\
$\mathrm{Na}$ & $1.1^{\dagger}$ \\
$\mathrm{Ba}$ & $0.23^{\dagger}$ \\
$\mathrm{Mn}$ & $013^{{ }^{+}}$ \\
$\mathrm{Sr}$ & $0.032^{\dagger}$ \\
$\mathrm{Cu}$ & $0007^{\dagger}$ \\
\hline
\end{tabular}

\footnotetext{
Mg, K, and Mn measured by both the methods are in good agreement

The value for $\mathrm{Na}$ has a large uncertainty.

"Values are determined by XRF.

tValues are determined by ICP-AES
}

Table 1b. Comparison of Elements at Normalized Element Ratio

\begin{tabular}{lllllll}
\hline & $\mathrm{Ca} / \mathrm{Al}$ & $\mathrm{Fe} / \mathrm{Al}$ & $\mathrm{Mn} / \mathrm{Al}$ & $\mathrm{K} / \mathrm{Al}$ & $\mathrm{Na} / \mathrm{Al}$ & $\mathrm{Si} / \mathrm{Al}$ \\
\hline X/Al [Bergametti, 1987] & 050 & 094 & 0.033 & 0.21 & 0.03 & 2.73 \\
X/Al (this study) & 0.45 & 090 & 0.015 & 0.15 & 0.13 & 270 \\
\hline
\end{tabular}




\author{
$F \quad$ flow rate $\left(\mathrm{L} \mathrm{min}^{-1}\right)$; \\ $R \quad$ rate of reaction in moles per time unit $\left(\mathrm{mol} \mathrm{min}^{-1}\right)$; \\ $V \quad$ volume of reactor $(\mathrm{L})$; \\ dn dissolved mole during dt period.
}

\subsection{Particulate Phase}

The $<20 \mu \mathrm{m}$ diameter fraction of a dry segregated loess sample collected on the northeastern part of Sal Island (Capo Verde Islands) was used as particulate phase. It is aeolian dust from Niger, deposited during the Holocene [Coudé-Gassen et al., 1994; Rognon et al., 1996]. We used loess, which can be considered as an analog to aerosol, to ensure enough quantity of the same material. This loess simulates atmospheric aerosols of a crustal origin, in particular of Saharan dust. It has the size distribution of a natural crustal aerosol particle, ranging from 1 to $100 \mu \mathrm{m}$ [Junge, 1979; Slinn, 1983; Coudé-Gaussen et al., 1987; Betzer et al., 1988].

An elemental analysis of this loess sample by $X$ ray fluorescence and inductively coupled plasma atomic emission spectrometry (after acid digestion) is presented in Table 1. The aluminium normalized element ratios in the loess are close to those measured for Saharan dust aerosols [Bergametti, 1987] except for $\mathrm{Na}$ which is due to local enrichments.

$\mathrm{X}$ ray diffraction examination of the loess sample was carried out on a Siemens D50 with a cobalt anticathode, covering a large angular field for detection of clay minerals, other silicates, and carbonates. The diffractogram indicates that this loess is made up of two parts: (1) a crystalline component of quartz plus sodic and potassic feldspars and micas (muscovite) and augite and (2) an amorphous component containing the clay minerals (kaolinite) and possibly iron oxo-hydroxides. We interpret these data as a weathering layer of amorphous silica with disordered clay minerals on top of crystalline material feldspars, micas, and probably augite [Pye, 1987]. Part of this amorphous layer was formed during postdeposition incipient meteorological alteration [Coudé-Gaussen et al., 1994].

\subsection{Experimental Procedure}

Experiments were conducted using $20 \mathrm{mg}$ of loess that was weathered with about $4 \mathrm{~L}$ of fresh solution for about 2 hours. This period is consistent with the lifetime of cloud droplets due to reevaporation [Junge, 1964; Warneck, 1989]. The volume of the

Table 2. Element Detection Limits

\begin{tabular}{|c|c|}
\hline Elements & Detection Limits, ppb \\
\hline \multicolumn{2}{|c|}{$\begin{array}{c}\text { Inductively Coupled Plasma Atomic Emission } \\
\text { Spectrometry }\end{array}$} \\
\hline Barıum & 0.5 \\
\hline Calcium & 0.6 \\
\hline Iron & I \\
\hline Magnesium & 0.01 \\
\hline Potassium & 0.5 \\
\hline Silıcium & 1 \\
\hline Sodium & 0.3 \\
\hline Strontium & 0.005 \\
\hline \multicolumn{2}{|c|}{ Atomic Absorption Spectrometry } \\
\hline Copper & 0.002 \\
\hline Iron & 0.005 \\
\hline Manganese & 0.004 \\
\hline
\end{tabular}

Detection limits are defined as 3 times the standard deviation of at least 10 measurements near blank levels.

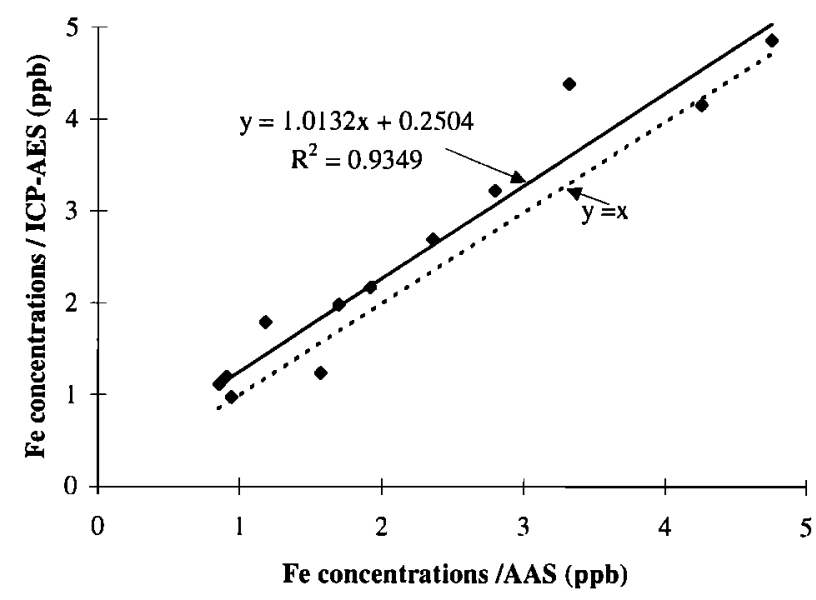

Figure 2. Intercalibration of atomic absorption spectrometry (AAS) / inductively coupled plasma atomic emission spectrometry (ICP-AES) for Fe at a concentration greater than 1 $\mathrm{ppb}$. This value is the lower limit for reasonably good ICP measurements for the conditions used in our experiments.

aqueous phase is very large in comparison with the small amount of loess, which is consistent with the observed cloud conditions.

In order to determine the effect of $\mathrm{pH}$ on aerosol dissolution, the weathering solution was prepared by dilution of a primary solution of Milli- $Q^{\mathrm{TM}}$ water, exactly acidified at $\left[\mathrm{H}^{+}\right]=1.0010^{-2} \mathrm{~mol} \mathrm{L^{-1 }}$. This raw solution was made with ultrapure Prolabo ${ }^{\mathrm{TM}}$ Normatom(B) hydrochloric acid and measured by a classical $\mathrm{NaOH}$ conductimetric titration. Input $\mathrm{pH}$ values of $3.80,4.00,4.30,4.70,5.00$, and 5.30 were used for transition metals $(\mathrm{Cu}, \mathrm{Fe}$, and $\mathrm{Mn})$ and $\mathrm{pH}$ values of $4.00,4.70$, and 5.00 were used for $\mathrm{Na}, \mathrm{Mg}, \mathrm{Si}, \mathrm{K}, \mathrm{Ca}, \mathrm{Sr}$, and $\mathrm{Ba}$. These values are similar to those in rainwater [Lim and Jickells, 1990] and cloud water [Romer et al., 1985]. The flow of input and output solution was fixed to $18 \mathrm{~mL} \mathrm{~min}^{-1}$. The regularity of the flow was checked all along the experiments by measuring the volume of each sample because this parameter is a key parameter in calculations of the dissolution rate ( $F$ in (1)). Each sample took about $1 \mathrm{~min}$ and $30 \mathrm{~s}$. The samplings were spaced by gaps ranging from $15 \mathrm{~s}$ at the beginning to $30 \mathrm{~min}$ at the end of the experiment. Sample solution was collected in polyethylene or polypropylene bottles that were carefully washed to remove species that could contaminate the solution [Losno et al. 1991]. The collected sample solutions were acidified at $\mathrm{pH} 1$ with ultrapure Prolabo ${ }^{\mathrm{TM}}$ Normatom® $\mathrm{HNO}_{3}$ to allow proper analyses. Four to seven blank samples were made for each experiment.

The concentrations of $\mathrm{Na}, \mathrm{Mg}, \mathrm{Si}, \mathrm{K}, \mathrm{Ca}, \mathrm{Fe}, \mathrm{Sr}$, and $\mathrm{Ba}$ released into the solution were measured with a Perkin-Elmer Optima 3000 inductively coupled plasma atomic emission spectrometry (ICP-AES), and those of $\mathrm{Mn}, \mathrm{Fe}$, and $\mathrm{Cu}$ were measured with an Unicam TGH Solaar 929 graphite furnace atomic absorption spectrometry (GFAAS). The detection limits are summarized in Table 2. Because the reported data may include values obtained with both instruments, we ensured the correspondence of results between the two analytical methods. Results given by both instruments were compared for iron which exhibited a wide overlapping analytical range. The result of this intercalibration shows good agreement within the analytical instrument performance (Figure 2 ) and allows us to use one or the other of the analytical methods.

The experimental conditions enabled us to use very low concentrations of about $\mu \mathrm{g} \mathrm{L}^{-1}$ (ppb) or less. To avoid extraneous contamination and to ensure very low detection limits, all 


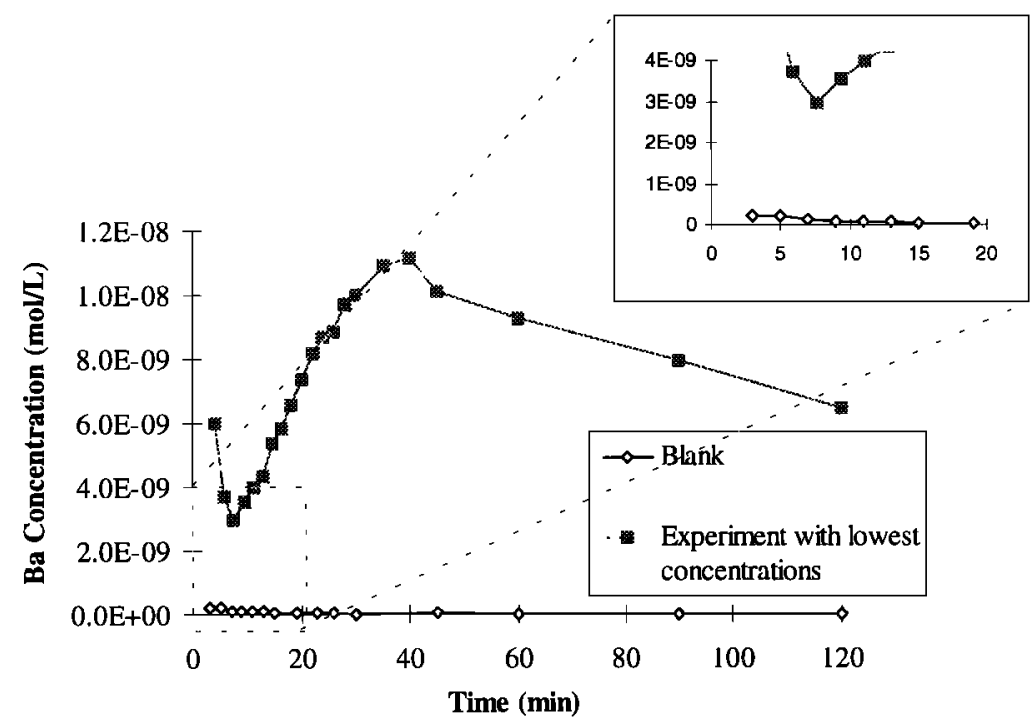

Figure 3. Dissolution concentration curves of the blank and nonblank experiments for $\mathrm{Na}$ and $\mathrm{Ba}$.

dissolution experiments and analyses were conducted in a clean room (class $<1000$ ) and with laminar-flow ultraclean benches (class $<10$ ), using ultraclean trace metal protocols [Boutron et al., 1990; Losno et al., 1991]. The temperature in the clean room was maintained between $20^{\circ}$ and $22^{\circ} \mathrm{C}$.

\section{Experimental Conditions}

\subsection{Blanks}

Two experiments were carried out without any particulate phase to demonstrate the absence of contamination during the experimental protocol. The results of these blanks were reproducible. In general, none of the investigated elements were detected except during the first $10 \mathrm{~min}$ of each experiment. During these first minutes, blank values were never below detection limit but remained negligible. The worst case was for $\mathrm{Ba}$ at $\mathrm{pH} 4.7$ and $9 \mathrm{~min}$ and showing blank concentration less than $10 \%$ of experimental concentration (Figure 3). This probably resulted from a late rinsing of the system which cannot be changed without a much more extensive cleaning protocol; this was not considered necessary based on the results shown in Figure 3 . We believe that the measured values represent dissolution of the loess sample and that they are free of contamination.

\subsection{Ionic Composition of Medium}

The weathering solution initially contained water and acid. During the experiment other ions are released by particle dissolution, especially $\mathrm{Na}^{+}$. The $\mathrm{pH}$ of the weathering solution was checked with a $\mathrm{pH}$ meter ( 0.02 units sensitivity) before the experiment, after $30 \mathrm{~min}$, and again at the finish of each experiment. The $\mathrm{pH}$ did not vary between entry and exit of the reactor and matched the anticipated $\mathrm{pH}$ values after dilution of the raw solution. We compared the $\mathrm{H}^{+}$concentrations with respect to the concentrations of other major cations as a function of time during the experiments (Table 3 ). The results show that $\mathrm{H}^{+}$is not the major ion after $1 \mathrm{~min}$, but it becomes dominant at 30 $\min$.

\subsection{Reproducibility}

Some fraction of the loess adhered to the top filter during the experiment. Several experiments were carried out to test this issue. The filter was removed from the system, dried, and weighed after 7,15 , and $30 \mathrm{~min}$. The filter caught 10 to $30 \%$ of loess (Table 4). Three replicate experiments were carried out, and the maximum difference between concentrations found in the outgoing solution was $\sim 5 \%$ for the first $30 \mathrm{~min}$ and $\sim 15 \%$ at the end of the experiments (Figures $4 \mathrm{a}$ and $4 \mathrm{~b}$ ). In this last case, the concentrations were close to the detection limits and were prone to greater analytical errors. From these results, we deduced that the amounts of captured loess on the filter did not significantly affect the measured dissolution rates.

\subsection{Dissolution Equilibrium}

For the elements studied here, the solubility product was never reached with the possible exception being $\mathrm{Fe}^{\mathrm{ll1}}$ with respect to crystalline oxo hydroxy salts. Faust and Hoigné [1990] and Flynn [1984] showed that the very insoluble crystalline forms of

Table 3. Percentages of Major Ions Composition of Solution at $\mathrm{pH} 4.00$ and 5.00

\begin{tabular}{|c|c|c|c|c|c|}
\hline $\mathrm{pH}$ & Time Elapsed During Experiment & $\mathrm{H}^{+}, \%$ & $\mathrm{Na}^{+}, \%$ & $\mathrm{~K}^{+}, \%$ & $\mathrm{Ca}^{2+}, \%$ \\
\hline \multirow[t]{3}{*}{4.00} & $1 \mathrm{~min}$ & 500 & 43.2 & 5.50 & 0.90 \\
\hline & $30 \mathrm{~min}$ & 96.7 & 0.40 & 0.50 & 1.30 \\
\hline & $90 \mathrm{~min}$ & 99.6 & 003 & 0.04 & 0.30 \\
\hline \multirow[t]{3}{*}{5.00} & $3 \mathrm{~min}$ & 24.1 & 69.4 & 4.70 & 0.70 \\
\hline & $30 \mathrm{~min}$ & 68.7 & 730 & 5.00 & 12.6 \\
\hline & $45 \mathrm{~min}$ & 74.8 & 6.90 & 4.50 & 9.40 \\
\hline
\end{tabular}


Table 4. Amount of Loess Captured on the Filter at Three Different Manipulation Times

\begin{tabular}{lccc}
\hline & Amount at $7 \mathrm{Min}, \mathrm{mg}$ & Amount at $15 \mathrm{Min}, \mathrm{mg}$ & Amount at $30 \mathrm{Min}, \mathrm{mg}$ \\
\hline Experiment 1 & 3.5 & 3.6 & 5.6 \\
Experiment 2 & 7.0 & 70 & 6.9 \\
Experiment 3 & 27 & 3.1 & 4.2 \\
Experiment 4 & 6.1 & 6.1 & 3.1 \\
Median & $4.80(24.00 \%)$ & $4.85(24.25 \%)$ & $4.90(24.50 \%)$ \\
Standard deviation & $2.05(102 \%)$ & $212(10.6 \%)$ & $1.65(8.25 \%)$ \\
\hline
\end{tabular}

The initial quantity in each experiment was $20 \mathrm{mg}$.

$\mathrm{Fe}^{\mathrm{III}}$ salts (especially $\mathrm{FeOOH}$, Goethite) are dissolved or formed too slowly. These salts do not affect our experiments that were completed after 120 min. Faust and Hoigné [1990] and Flynn [1984] also showed that amorphous hydroxides can interfere with equilibrium conditions. Thus, to prove that our cell operated well below the saturation limit, we made several calculations to evaluate the more probable amorphous form, that is, $\mathrm{Fe}(\mathrm{OH})_{3}$ (ferrihydrite).

The relevant equilibria at $25^{\circ} \mathrm{C}$ are (Stumm and Morgan, 1996; Turner et al., 1981):

$\begin{array}{ll}\mathrm{Fe}(\mathrm{OH})_{3(\text { sold } \mathrm{d})}+3 \mathrm{H}^{+}=\mathrm{Fe}^{3+}+3 \mathrm{H}_{2} \mathrm{O} & \log K_{S}=3.96 \\ \mathrm{Fe}^{3+}+\mathrm{H}_{2} \mathrm{O}=\mathrm{FeOH}^{2+}+\mathrm{H}^{+} & \log B_{l}=-2.19\end{array}$

(a)

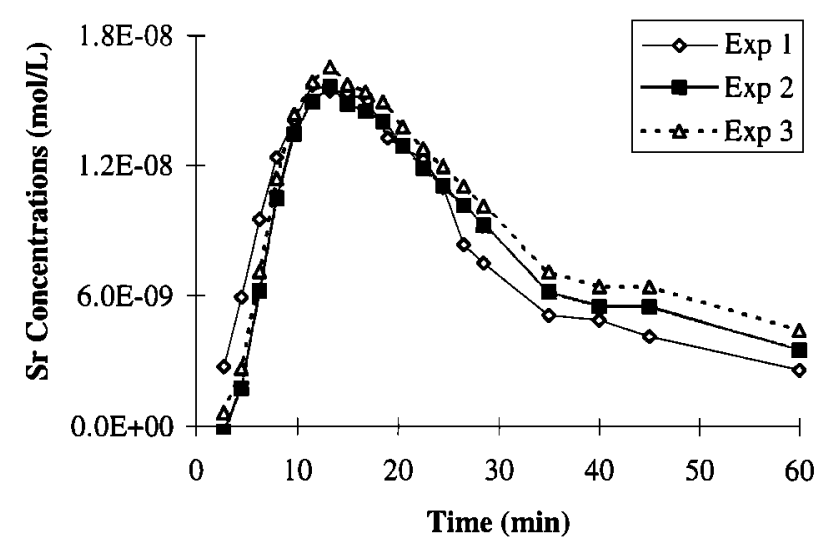

(b)

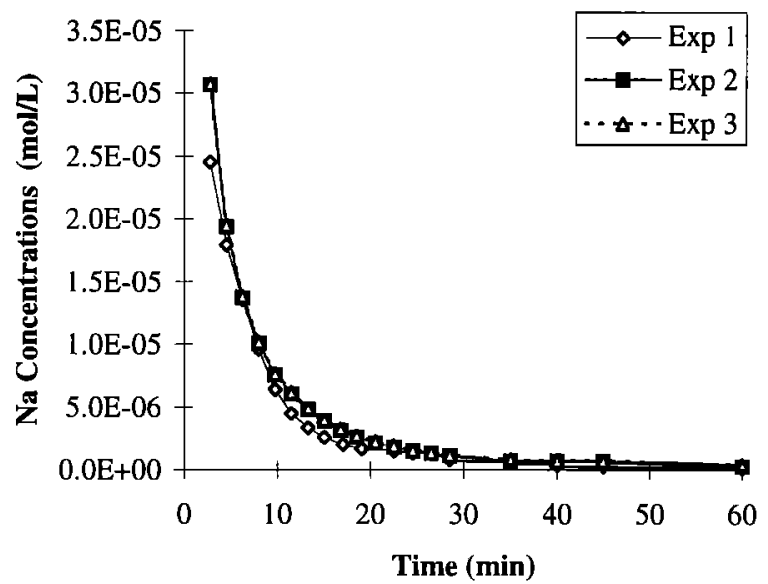

Figure 4. Example of reproducibility of three experiments carried out in the same conditions but at different days for (a) $\mathrm{Sr}$, and (b) $\mathrm{Na}$.

$$
\begin{array}{ll}
\mathrm{Fe}^{3+}+2 \mathrm{H}_{2} \mathrm{O}=\mathrm{Fe}(\mathrm{OH})_{2}{ }^{+}+2 \mathrm{H}^{+} & \log \beta_{2}=-5.67 \\
\mathrm{Fe}^{3+}+3 \mathrm{H}_{2} \mathrm{O}=\mathrm{Fe}(\mathrm{OH})_{3}{ }^{0}+3 \mathrm{H}^{+} & \log \beta_{3}=-12.0 \\
\mathrm{Fe}^{3+}+4 \mathrm{H}_{2} \mathrm{O}=\mathrm{Fe}(\mathrm{OH})_{4}{ }^{-}+4 \mathrm{H}^{+} & \log \beta_{4}=-21.6 \\
\mathrm{Fe}^{3+}+\mathrm{Cl}^{-}=\mathrm{FeCl}^{2+} & \log \beta_{\mathrm{Cl}}=1.48
\end{array}
$$

The chloride complex is negligible $B_{\mathrm{Cl}}\left[\mathrm{Cl}^{-}\right]<1$ thus

$$
\begin{aligned}
{\left[\mathrm{Fe}_{\text {tot }}\right] } & =\left[\mathrm{Fe}^{3+}\right]+\left[\mathrm{FeOH}{ }^{2+}\right]+\left[\mathrm{Fe}(\mathrm{OH})_{2}^{+}\right]+\left[\mathrm{Fe}(\mathrm{OH})_{3}\right] \\
& +\left[\mathrm{Fe}(\mathrm{OH})_{4}^{-}\right] \\
{\left[\mathrm{Fe}_{\text {tot }}\right] } & =\left[\mathrm{Fe}^{3+}\right]\left(1+\beta_{1}\left[\mathrm{H}^{+}\right]^{-1}+\beta_{2}\left[\mathrm{H}^{+}\right]^{-2}+\beta_{3}\left[\mathrm{H}^{+}\right]^{-3}\right. \\
& \left.+\beta_{4}\left[\mathrm{H}^{+}\right]^{-4}\right)
\end{aligned}
$$

and

$$
\begin{gathered}
{\left[F e^{3+}\right]_{\max }=K s\left[H^{+}\right]^{3}} \\
\log \left[F e_{\text {tot }}\right]_{\max }=\log K s+\log \left(10^{-3 p H}+10^{\log \beta I-2 p H}+10^{\log \beta 2-p H}\right. \\
\left.+10^{\log \beta 3}+10^{\log \beta 4+p H}\right)
\end{gathered}
$$

Table 5 gives $\left[\mathrm{Fe}_{\mathrm{tot}}\right]_{\max }$ for the $\mathrm{pH}$ values of interest to our study. Note that in the range of the studied $\mathrm{pH}(3.80-5.30), \mathrm{Fe}^{\mathrm{III}}$ is always undersaturated with respect to solid $\mathrm{Fe}(\mathrm{OH})_{3}$. This result suggests that $\mathrm{Fe}^{\mathrm{III}}$ concentrations in our experiments were not affected by salt formation.

\section{Results and Discussion}

\subsection{Dissolution Rate}

When plotting reaction rate versus time, two types of curves were obtained, that is, a bell-shaped curve for $\mathrm{Mg}, \mathrm{K}, \mathrm{Ca}, \mathrm{Mn}, \mathrm{Sr}$ and $\mathrm{Ba}$ (Figure $5 \mathrm{a}$ ) or an experimental decrease in the dissolution rate to relatively low values for $\mathrm{Na}, \mathrm{Si}, \mathrm{Fe}$, and $\mathrm{Cu}$ (Figure 5b). Although the results from long-term dissolution studies are not specifically relevant to aerosol dissolution, these studies also showed similar initially high dissolution rates, such as a parabolic rate law in the case of batch reactor experiments [Wollast, 1967; Luce et al., 1972; Lagache, 1976; Holdren and Berner, 1979; Schott et al., 1981; Holdren and Speyer, 1985; Tole et al., 1986; Carroll-Webb and Walther, 1988]. In order to explain the parabolic dissolution kinetics, two different mechanisms have been proposed. First, it was assumed that the rate of weathering was controlled by a surface layer through which the reactants and reaction products diffused [Wollast, 1967; Luce et al., 1972; Paces, 1973; Chou and Wollast, 1984; Wollast and Chou, 1985; Holdren and Speyer, 1985]. Second, surface controlled dissolution of fine-grained material, high-strain areas on large grains, defects and grain boundary diffusion [Holdren and 
Table 5. [ $\mathrm{Fe}^{\mathrm{III}}$ tot] in Equilibrium With Ferrihydrite $\mathrm{Fe}(\mathrm{OH})_{3}$ at Different $\mathrm{pH}$ Values

\begin{tabular}{lcccccc}
\hline $\mathrm{Fe}(\mathrm{OH})_{3}$ & $\mathrm{pH}=3.8$ & $\mathrm{pH}=4$ & $\mathrm{pH}=4.3$ & $\mathrm{pH}=4.7$ & $\mathrm{pH}=5$ & $\mathrm{pH}=5.3$ \\
\hline $\mathrm{Fe}_{\text {tot max }} \mathrm{ppb}$ & 257.73 & 142.80 & 63.41 & 23.55 & 1172 & 6.04 \\
$\mathrm{Fe}_{\text {mees max }} \mathrm{ppb}$ & 2.65 & 4.54 & 5.01 & 7.04 & 7.48 & 478 \\
\hline
\end{tabular}

Log Ks $=3.96$ [Stumm and Morgan, 1996].

Berner, 1979; Schott et al., 1981; Petrovich, 1981, Helgeson et al., 1984; Lasaga, 1984] were assumed.

To explain the bellshape of our curves, we applied the surface complex-controlled dissolution approach by Stumm and Furrer [1987], Stumm and Wollast [1990], and Stumm and Morgan [1996]. The surface of hydrous oxides and hydrated silicates contains hydroxyl surface groups that are able to coordinate with $\mathrm{H}^{+}$and $\mathrm{OH}^{-}$, that is, surface protonation and deprotonation. Surface protonation polarizes, weakens, and tends to break the critical metal-oxygen lattice bonds enabling the detachment of central metal cations that enter the solution. Dissolution reactions may start as an attack by protons of the mineral surface preferentially at points of excess surface energy. A simple scheme of the proton adsorption can be proposed to explain the increased rates:

$$
\begin{array}{rlr}
k_{H}^{\prime}=\left[H^{+}\right]^{n} k_{H} \\
{[\mathrm{~S}-\mathrm{X}]+n \mathrm{H}^{+}} & \rightarrow \quad\left[\mathrm{SH}_{\mathrm{n}}-\mathrm{X}\right] \\
& k_{L} \\
{\left[\mathrm{SH}_{\mathrm{n}}-\mathrm{X}\right]} & \rightarrow \quad \mathrm{S}_{\text {aqueous }}+n \mathrm{H}^{+}+\mathrm{X}
\end{array}
$$

the dissolution rate during the first phase of dissolution, when the rates increase can be written as

$$
R=k_{L}\left[S H_{n}-X\right]
$$
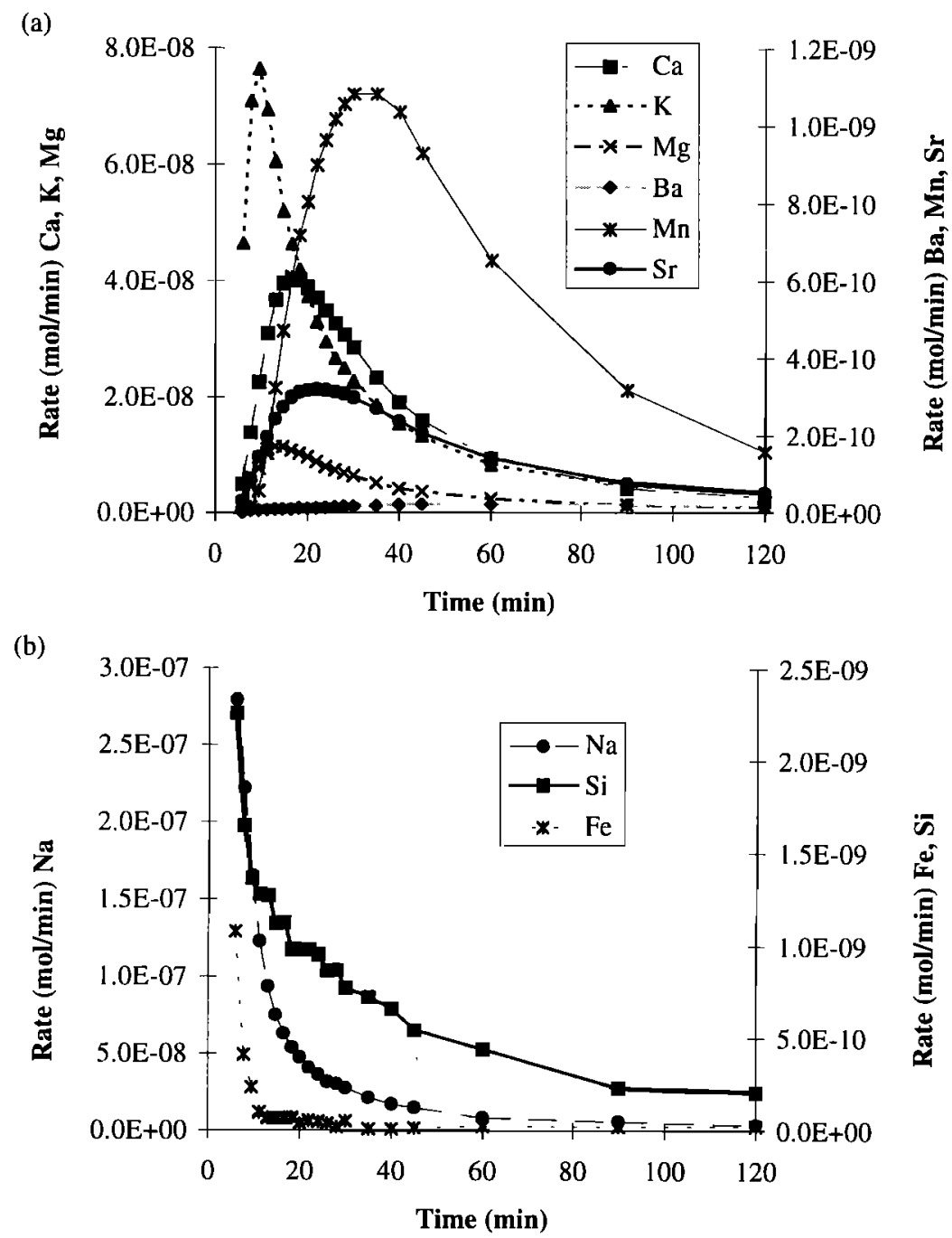

Figure 5. Shapes of dissolution rate curves for the elements: (a) bell shaped dissolution curves at $\mathrm{pH} 4.7$, showing initially strong increasing dissolution rates followed by a gradual decrease, and (b) monotonically decreasing dissolution rates at $\mathrm{pH} 4.7$. 

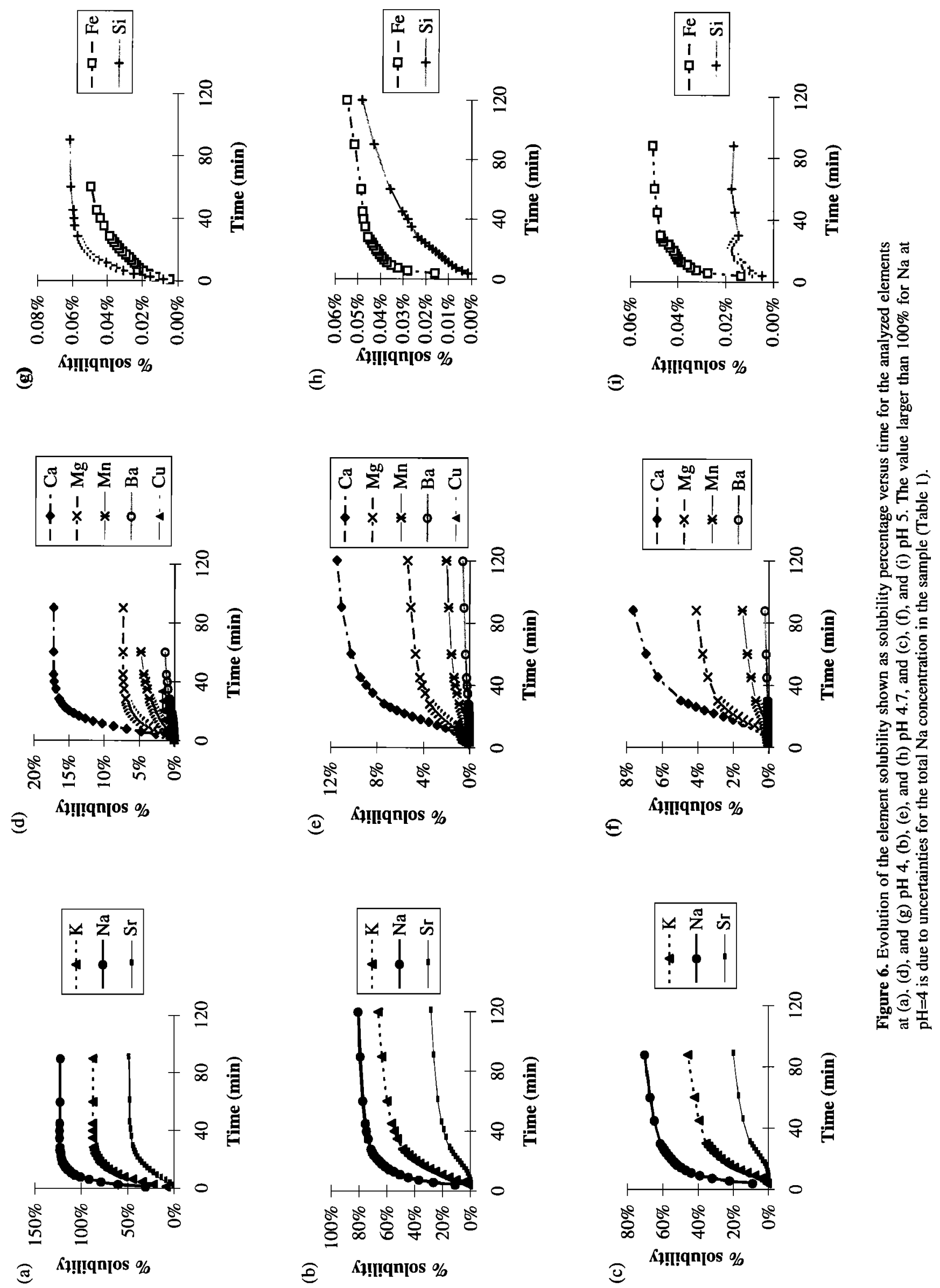
Assuming a first order law for $[\mathrm{S}-\mathrm{X}]$ in reaction (8)

$$
\begin{gathered}
d\left[S H_{n}-X\right] / d t=k_{H}^{\prime}\left([S-X]_{0}-\left[S H_{n}-X\right]_{t}\right) \\
R=k_{L}[S-X]_{0}\left(1-\mathrm{e}^{-k_{H}^{\prime} t}\right)
\end{gathered}
$$

where

$$
\begin{array}{ll}
\mathrm{R} & \text { the dissolution rate }\left(\mathrm{mol} \mathrm{cm} \mathrm{min}^{-1}\right) ; \\
k_{L} & \text { the rate constant of } \mathrm{X} \text { release }\left(\mathrm{min}^{-1}\right) ; \\
{[\mathrm{S}-\mathrm{X}]_{0}} & \text { number of the free surface sites for } \mathrm{t}=0\left(\mathrm{~mol} \mathrm{~cm}^{-2}\right) ; \\
k_{H} \text { and } k_{H}^{\prime} \text { the rate constant and the apparent rate constant of } & \text { surface protonation, respectively. }
\end{array}
$$

In this scheme, increasing dissolution rates at the front of the bell-shaped curve are caused by the exchange of $\mathrm{H}^{+}$at the surface. $\mathrm{H}^{+}$is not always the major cation in the solution (Table 3 ), and a contribution of $\mathrm{Na}^{+}$to ion exchange cannot be excluded. During the initial phase, fast surface protonation is followed by the slow and rate-determining release of element from mineral. The dissolution of amorphous rather than crystalline minerals probably dominates the earliest dissolution. After this first stage, either of the two previously mentioned hypotheses might explain the decrease in dissolution rates because the hydrated layer thickens or the surface reactivity is reduced by the complete dissolution of fine grains.

As both bell-shaped and monotonically decreasing curves are obtained, it appears that some elements are more prone to go into solution than others. The monotonic curves for $\mathrm{Na}, \mathrm{Si}, \mathrm{Fe}$, and $\mathrm{Cu}$ could be interpreted as bell-shaped but with $\mathrm{k}_{\mathrm{H}}^{\prime}$ too high for observation. Copper and iron are mostly in amorphous fraction of loess and should be highly reactive. Silicon comes from the mineral lattice or from amorphous $\mathrm{SiO}_{2}$ at the surface. Sodium may be released swiftly because of rapid exchange of protons at feldspar surfaces and by dissolution of halite crystals.

The relative rate of release of the elements can be expressed as the percentage of the accumulated dissolved mass at the end of each experiment. The observed sequence of increasing solubility becomes $\mathrm{Si}<\mathrm{Fe}<\mathrm{Ba}<\mathrm{Mn}<\mathrm{Mg}<\mathrm{Ca}<\mathrm{Sr}<\mathrm{K}<\mathrm{Na}$ (Figure 6). This relative order was also obtained by Hoffmann et al. [1997] for the same elements, and for Fe and Mn [Spokes et al., 1994], in other dissolution experiments. Alkaline and alkaline-earth ions $(\mathrm{Na}, \mathrm{K}, \mathrm{Mg}$, and $\mathrm{Ca}$ ) inserted in the lattice dissolve more rapidly than other metals. Silicon, being the primary network constituent, is the least soluble. For all elements except $\mathrm{Fe}$ and $\mathrm{Cu}$ (Figure 6b, $6 \mathrm{c}, 6 \mathrm{e}, 6 \mathrm{f}, 6 \mathrm{~h}, 6 \mathrm{i})$, releases into the solution increase when $\mathrm{pH}$ decreases (Figure 6a-6i). This is in agreement with our proposed hydration mechanism. It also partially explains the different levels found in rainwater, which Spokes et al. [1994] pointed out.

The elements have different hydration reactivity as shown by the shift of maxima of bell shaped dissolution curves as a function of time. Fe and $\mathrm{Si}$ are released slower than the other elements. They exhibit monotonic dissolution behavior, suggesting that the hydration process is very fast and is welladvanced before we collected the first sample. This behavior supports the hypothesis that $\mathrm{Fe}$ and $\mathrm{Si}$ are dissolved from an amorphous phase. For $\mathrm{Fe}$, this is in good agreement with the presumed nonreactivity of crystalline oxo-hydrated salts.

\subsection{The pH Influence}

$\mathrm{Na}, \mathrm{Mg}, \mathrm{Si}, \mathrm{K}, \mathrm{Ca}, \mathrm{Mn}, \mathrm{Sr}$, and $\mathrm{Ba}$ dissolution and hydration rates generally increase with decreasing $\mathrm{pH}$. Moreover, the shapes of the dissolution curves become monotonic at $\mathrm{pH} 4.00$ for all elements (as shown for Ca in Figure 7). This is in good agreement with the increase of the protonation step expressed in (8) and (10): at $\mathrm{pH} 4.00$, the protonation rate is too fast to be observed and occurs before the first sample collection. The Fe and $\mathrm{Cu}$ curves have similar shape and do not exhibit large variations in the range of $\mathrm{pH}$ studied (Figure 8a and 8b; see below).

The $\mathrm{pH}$ dependency of dissolution can be explained by the approach outlined above, as the apparent rate constant decreases with decreasing $\mathrm{pH}$. The value of $\mathrm{k}_{\mathrm{H}}^{\prime}$ was calculated for $\mathrm{pH} 4.70$ and 5.00 in the step of increasing dissolution rate for the experiments that produced the bell-shaped curves, assuming constant $\mathbf{k}_{\mathbf{L}}$ :

$$
\begin{aligned}
\frac{d R}{d t} & =-k_{L}[S-X]_{0} k_{H}^{\prime} \mathrm{e}^{-k_{H}^{\prime}} \\
\ln \left(\frac{d R}{d t}\right) & =\ln \left(k_{L}[S-X]_{0} k_{H}^{\prime}\right)-k_{H}^{\prime} t
\end{aligned}
$$

The plot of $\ln \left(\frac{d R}{d t}\right)=f(t)$ is used to calculate $k_{H}^{\prime}$, the slope of the linear regression (Table 6) at two different pHs. The exponent $\mathrm{n}$ is then calculated as

$$
n=\log \left[\left(k_{H_{1}}^{\prime} / k_{H_{2}}^{\prime}\right) /\left(p H_{2}-p H_{1}\right)\right]
$$

Between $\mathrm{pH} 4.70$ and $5.00, \mathrm{k}_{\mathrm{H}}^{\prime}$ decreases, and $\mathrm{n}$ is positive (Table 6). It is interesting to note that the $\mathrm{pH}$ dependency of the rate constants follows, at least qualitatively, the $\mathrm{pH}$ dependency of mineral solubility. Thus $n$ values in the range [0.3 -2.81$]$ are found to decrease for elements in the same column of the periodic table, that is. $\mathrm{Mg}$ to $\mathrm{Sr}$ (see Table 6). The results emphasize that the affinity of a mineral to form complexes with $\mathrm{H}^{+}$varies according to the elements that compose this mineral. The elements with the highest percentages of release have the lowest values of $n$, and they require the exchange of less $\mathrm{H}^{+}$to be leached $(\mathrm{Ca}<\mathrm{Mg}<\mathrm{Mn})$. However, keeping in mind that only two points were used to calculate $n$, the values in Table 6 are only approximations.

Figure 7 shows that the dissolved rate for calcium is much faster at the beginning for $\mathrm{pH} 4.00$ than at higher $\mathrm{pH}$. Yet the curve for $\mathrm{pH} 4.00$ crosses the high $\mathrm{pH}$ curves after 10 to $20 \mathrm{~min}$ and then becomes lower. To point out the effects of varying $\mathrm{pH}$ values on dissolution rates, a more useful parameter for comparison will be the reaction progress $\xi$ defined as

$$
\xi=\int_{t i n}^{t} R d t
$$

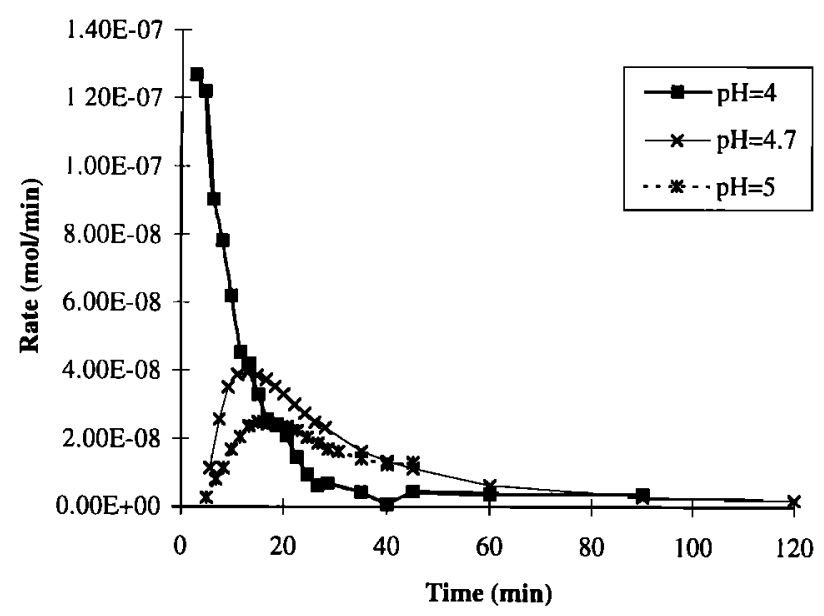

Figure 7. Examples of the effect of $\mathrm{pH}$ on $\mathrm{Ca}$ dissolution curves. Evolution of bell shaped curve toward monotone curve as $\mathrm{pH}$ decreases. 
(a)

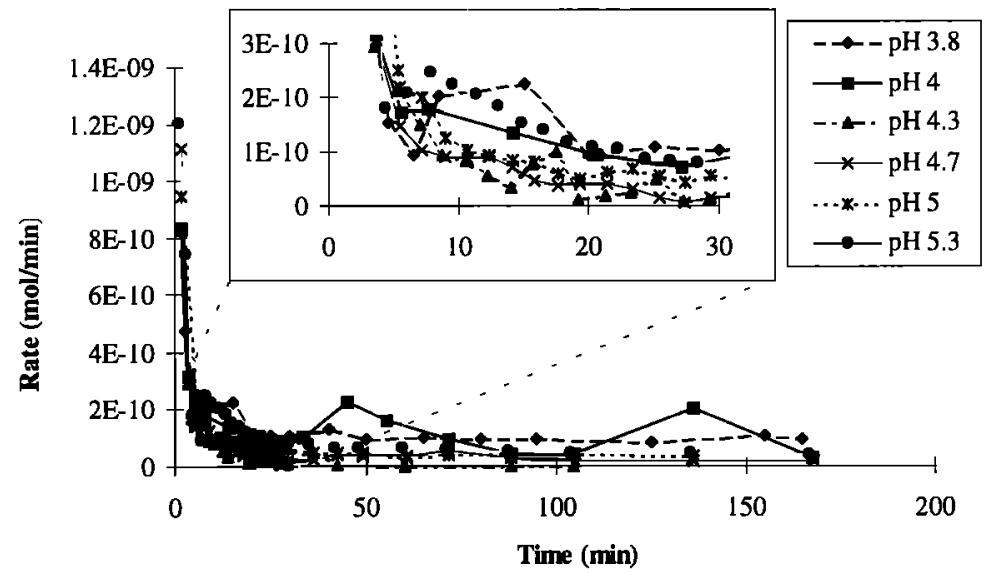

(b)

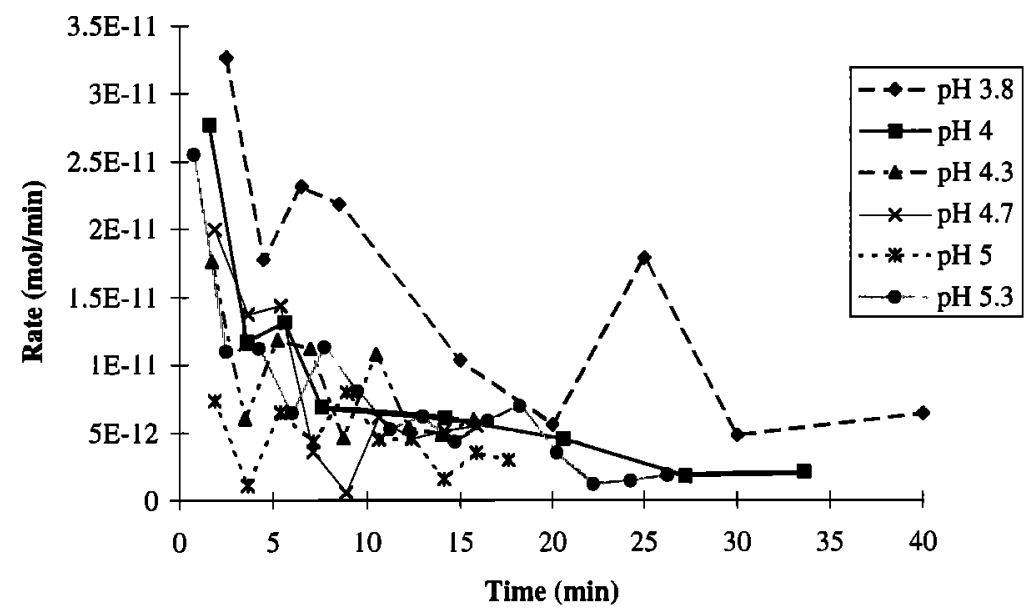

Figure 8. Effect of $\mathrm{pH}$ on the shape of the dissolution curve for (a) $\mathrm{Fe}$ and (b) $\mathrm{Cu}$. The influence of $\mathrm{pH}$ is less obvious than for the others elements.

Using equation (1) for $R$,

$$
\begin{gathered}
\xi=\int_{t n}^{t}\left(C(t) F+V \frac{d C}{d t}\right) d t=F \int_{t i n}^{t} C(t) d t+V \int_{t i n}^{t} \frac{d C}{d t} d t \\
\xi=F \int_{t i n}^{t} C(t) d t+V\left[C(t)-C\left(t_{\text {in }}\right)\right]
\end{gathered}
$$

Thus the total amount of dissolution of particulate phase can be calculated for different times:

$$
R=C(\xi) F+V \Delta C / \Delta t
$$

We express the percentage of $x$ dissolved as

$$
(x)_{\text {dls.solved }} \%=\frac{\xi M x}{0.020 P c(x)}
$$

where

$\xi \quad$ reaction progress in moles;

$\mathrm{M} x \quad$ atomic mass of element $x\left(\mathrm{~g} \mathrm{~mol}^{-1}\right)$;

0.020 amount of loess introduced in the reactor $(\mathrm{g})$;

$\operatorname{Pc}(x)$ percentage of $x$ in the loess (Table 1).

$\mathrm{Fe}$ and $\mathrm{Cu}$ dissolution are cast in this form and shown in Figure 9. Early $\mathrm{Fe}$ dissolution increases uniformly with $\mathrm{pH}$
(Figure 9a). Note that later fractions reach a minimum rate at $\mathrm{pH}$ 4.3 , suggesting that two different dissolution mechanisms operate over longer periods of time; at $\mathrm{pH}>4.3$ and at $\mathrm{pH}<4.3$. The same behavior can be inferred for $\mathrm{Cu}$ with a rate minimum between $\mathrm{pH} 4.5$ and 5 (Fig. 9b). These observations suggest that $\mathrm{Cu}$ and $\mathrm{Fe}$ are released by different mechanisms at the beginning and at the end of the experiment. This probably reflects two different mineralogical forms of $\mathrm{Cu}$ and $\mathrm{Fe}$ in the loess sample. The first form that was regularly influenced by $\mathrm{pH}$ changes is probably an amorphous phase which seems to be completely removed after several minutes of dissolution.

The dissolution rate law can be obtained by adding both mechanisms:

Table 6. Calculation of the $k_{H}^{\prime}$ Hydration Constant $\left(\mathrm{min}^{-1}\right)$ of Mineral Surface Sites and $n$ Values

\begin{tabular}{ccccccc}
\hline & $\mathrm{pH}$ & $\mathrm{Ba}$ & $\mathrm{Ca}$ & $\mathrm{Mg}$ & $\mathrm{Mn}$ & $\mathrm{Sr}$ \\
\hline$k_{H}^{\prime}$ & 4.7 & 0.2667 & 0.0650 & 0.1068 & 1.2269 & 0.1298 \\
& 5 & 0.1011 & 0.0446 & 0.0631 & 0.1752 & $0.105 \mathrm{I}$ \\
$n$ & & 1.4 & 0.55 & 0.75 & 2.81 & 0.3 \\
\hline
\end{tabular}

The $\mathrm{n}$ value is the parameter of affinity of these sites with protons obtained from the $\ln (\mathrm{dv} / \mathrm{dt})=\mathrm{f}(\mathrm{t})$ plots. 
(a)

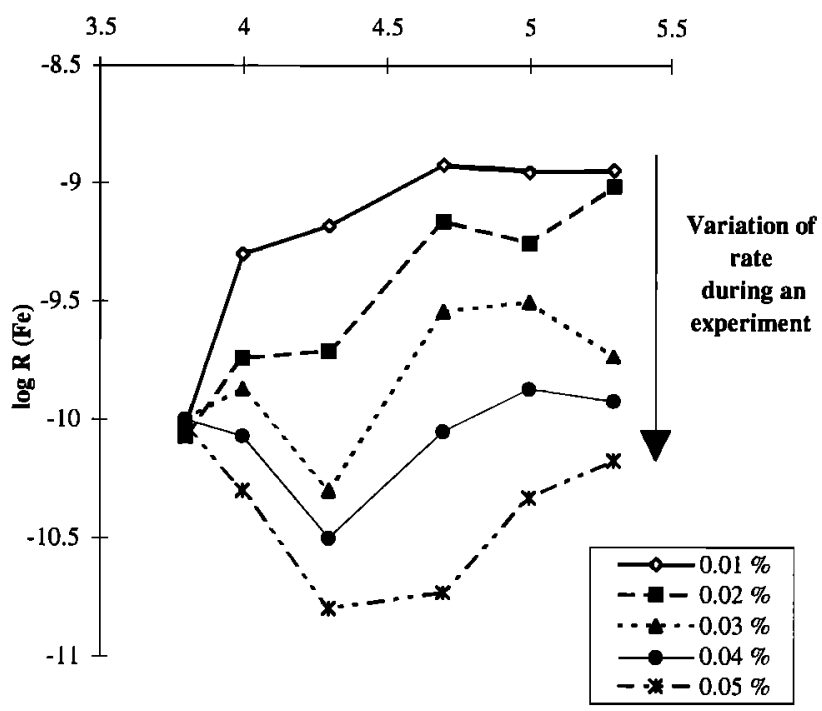

(b)

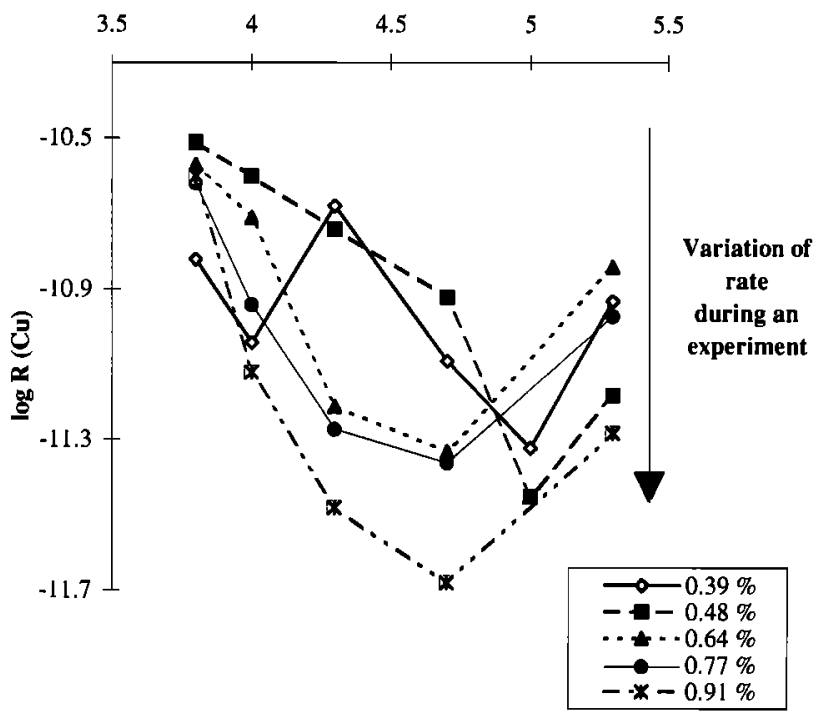

Figure 9. Evolution of release rate as a function of $\mathrm{pH}$ for different dissolved fractions and calculations of $\mathrm{pH}_{\mathrm{pzc}}$ for (a) $\mathrm{Cu}$ and (b) Fe.

$$
\begin{gathered}
R=k\left[H^{+}\right]^{u}+k^{\prime}\left[H^{+}\right]^{-b} \\
\log R=\log \left(k\left[H^{+}\right]^{a}+k^{\prime}\left[H^{+}\right]^{-b}\right)
\end{gathered}
$$

with two different situations.

1. If $\mathbf{k}\left[\mathrm{H}^{+}\right]^{\mathrm{d}} \ll \mathbf{k}^{\prime}\left[\mathrm{H}^{+}\right]^{-\mathrm{b}}$; $\log \mathrm{R}=\log \mathrm{k}^{\prime}+\mathrm{b} \mathbf{p H}$. This equation represents the part of the line with positive slope. As the $\mathrm{H}^{+} / \mathrm{OH}^{-}$ equilibrium is always very fast, we obtain $\mathrm{k}^{\prime}\left[\mathrm{H}^{+}\right]^{-\mathbf{b}}=\mathrm{k}^{\prime} \mathrm{K}_{\mathrm{w}}^{-\mathrm{b}}$ $\left[\mathrm{OH}^{-}\right]^{b}$ to emphasize reaction control by $\mathrm{OH}^{-} \mathrm{s}\left(\mathrm{K}_{\mathrm{w}}\right.$ is the equilibrium constant of water ionic dissociation).

2. If $\mathrm{k}\left[\mathrm{H}^{+}\right]^{\mathrm{a}} \gg \mathrm{k}^{\prime}\left[\mathrm{H}^{+}\right]^{-\mathrm{b}} ; \log \mathrm{R}=\log \mathrm{k}-\mathrm{a} \mathrm{pH}$. This equation represents the part of the line where the slope is negative. The reaction is controlled by protons.

The best fit with rate laws and the rate coefficients are given in Table 7. Similar compound rate laws describing mineral dissolution have been summarized by Stumm and Morgan [1996] who introduced the zêta $\mathrm{pH}$ of a mineral $\left(\mathrm{pH}_{\mathrm{pzc}}\right)$. Typically, the proton-controlled mechanism dominates dissolution at $\mathrm{pH}<\mathrm{pH}_{\mathrm{pz}}$, and hydroxyl-controlled dissolution dominates the overall dissolution at $\mathrm{pH}>\mathrm{pH}_{\mathrm{pzc}}$. A similar $\mathrm{pH}$-dependence law was also reported by Brady and Walther [1989], who considered the detachment rates of the silicate oxide components through surface protonation-deprotonation reactions. The $\mathrm{pH}_{\mathrm{pzc}}$ estimated from our rate measurements ranges between $\mathrm{pH} 4.2$ and 4.7 for $\mathrm{Fe}$ and between $\mathrm{pH} 4.6$ and 5.1 for $\mathrm{Cu}$. The point of zero charge of the mineral depends on the $\mathrm{pH}$, the concentrations of all ions, the degree of hydration, and the degree of crystallinity of the dissolving solids [Stumm and Morgan, 1996]. The differences found for $\mathrm{pH}_{\mathrm{pzc}}$ are probably explained by different hydrated oxides and minerals that contain the studied elements.

For the other elements, rates decrease with increasing $\mathrm{pH}$, and no hydroxyl-controlled dissolution is observed (Figures 10a-10e), suggesting that the $\mathrm{pH}_{\mathrm{pzc}}$ point for these elements is greater than 5.30. Rate coefficients for these elements are shown in Table 8. The behavior of $\mathrm{Mn}$ is somewhat of an exception with a break of slope at pH 4 (see Fig. 10 f) that was also observed by Statham and Chester [1988]. The composite rate law cannot be applied because the point at $\mathrm{pH} 4$ corresponds to a maximum.

\section{Conclusion}

An open flow reactor was used to study the aerosol dissolution in atmospheric waters. The simultaneous measurements of the elements $\mathrm{Na}, \mathrm{Mg}, \mathrm{Si}, \mathrm{K}, \mathrm{Ca}, \mathrm{Mn}, \mathrm{Fe}, \mathrm{Cu}, \mathrm{Sr}$, and $\mathrm{Ba}$ allowed us to model the mechanistic steps involved in the weathering of Saharan derived dust aerosol weathering. Our primary observations are as follows:

1. Aqueous dissolution is a two-stage process. The first step consists of an attack by $\mathrm{H}^{+}$or $\mathrm{OH}^{-}$of an amorphous and a crystalline phase. We have quantified this protonation by measuring hydration constants $\mathrm{k}_{\mathrm{H}}^{\prime}$, which characterize the fixation of protons on surface sites. This allowed us to model the interactions between the particulate and the aqueous phases at the onset of cloud droplet condensation.

2. We have measured the release variations of these elements as a function of $\mathrm{pH}$ ranging from 3.80 to 5.30 and found that $\mathrm{Fe}$ appears to be the least soluble element after $\mathrm{Si}$, which is in good agreement with the previously observed trends [see Spokes et al., 1994].

3. The $\mathrm{pH}$ has a critical role in the dissolution of elements. Typically, a decrease in $\mathrm{pH}$ will accelerate dissolution. For the transition metals $\mathrm{Fe}$ and $\mathrm{Cu}$, a compound rate law operates: protons control the dissolution at acid $\mathrm{pH}$, and hydroxyls control the dissolution at less acid $\mathrm{pH}$. The operation of a compound rate law points to the necessity to cover a large interval of $\mathrm{pH}$ values and does not allow the extrapolation from experimental results obtained at lower $\mathrm{pH}$ values.

Table 7. Values of Kinetic Parameters of Copper and Iron Dissolution as a Function of $\mathrm{pH}$ Values at Different

\begin{tabular}{|c|c|c|c|c|}
\hline Solubility, \% & a & $\log k$ & $b$ & $\log \mathrm{k}^{\prime}$ \\
\hline & \multicolumn{4}{|c|}{$C u$} \\
\hline 0.64 & 0.90 & -8.45 & 080 & -16.46 \\
\hline 0.77 & 0.81 & -896 & 0.65 & -15.71 \\
\hline 091 & 1.14 & -7.73 & 0.67 & -16.11 \\
\hline & \multicolumn{4}{|c|}{$\mathrm{Fe}$} \\
\hline 0.03 & 1.43 & -5.44 & 191 & -19.77 \\
\hline 0.04 & 1.03 & -7.32 & 0.62 & -14.30 \\
\hline 0.05 & 155 & -542 & 0.69 & -15.10 \\
\hline
\end{tabular}
Solubility Percentages

The $\mathrm{k}$ value is expressed in $\min ^{-1} \mathrm{mg}^{-1}$ 

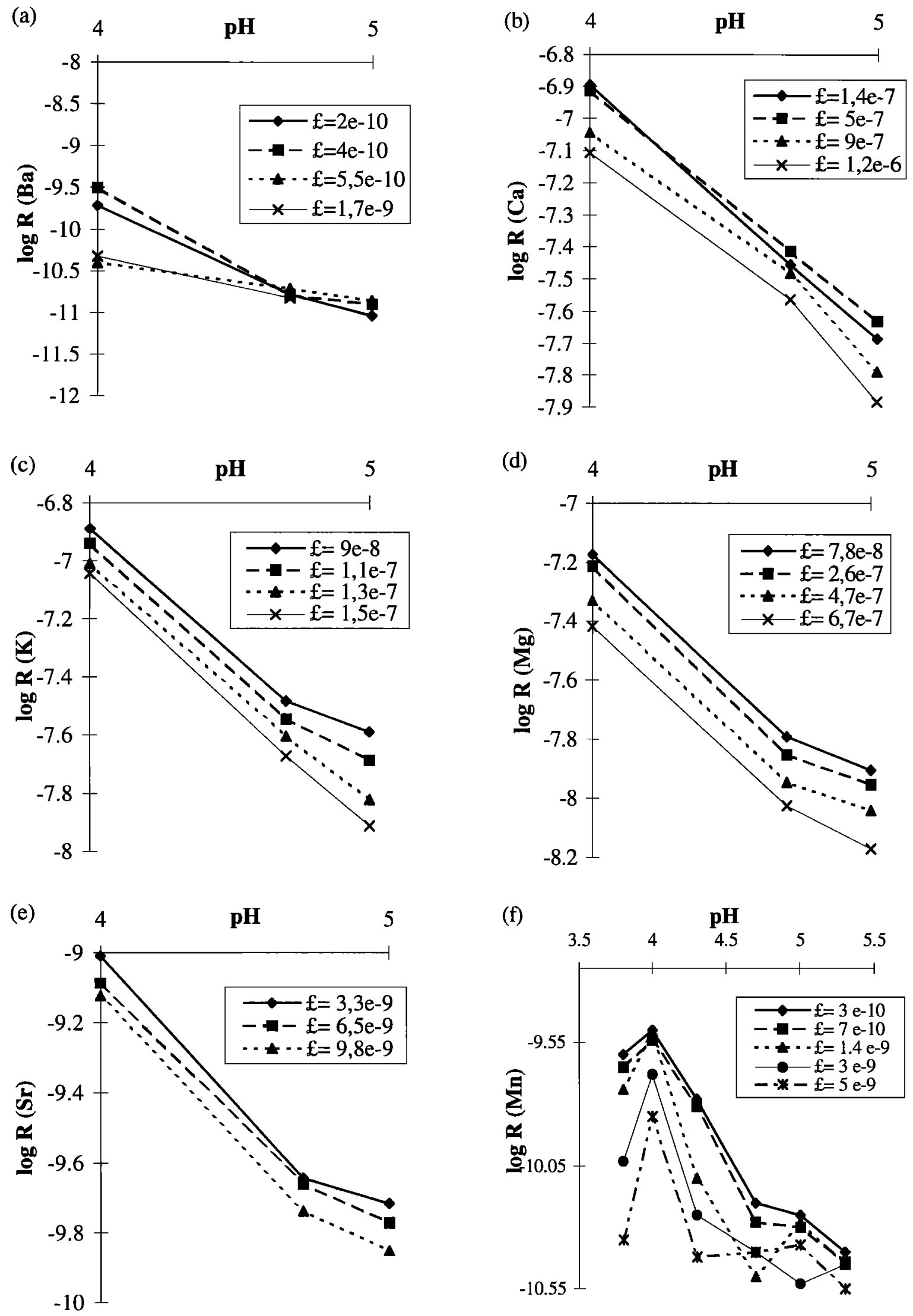

Figure 10. Evolution of dissolution rate as a function of $\mathrm{pH}$ for different dissolution steps, for (a) Ba, (b) Ca, (c) $\mathrm{K}$, (d) $\mathrm{Mg}$, (e) $\mathrm{Sr}$, and (f) $\mathrm{Mn}$. 
Table 8. Kinetic Parameter Values for $\mathrm{Ba}, \mathrm{Ca}, \mathrm{K}, \mathrm{Mg}$, and $\mathrm{Sr}$ Dissolution as a Function of $\mathrm{pH}$ Values at Different Solubility Percentages

\begin{tabular}{|c|c|c|c|}
\hline Element & Solubility, \% & a & $\log k$ \\
\hline \multirow[t]{4}{*}{$\mathrm{Ba}$} & 0.06 & 1.35 & -5.6 \\
\hline & 0.12 & 1.47 & -5.0 \\
\hline & 0.16 & 0.45 & -9.9 \\
\hline & 0.50 & 0.71 & -8.8 \\
\hline \multirow[t]{4}{*}{$\mathrm{Ca}$} & 0.74 & 0.79 & -5.0 \\
\hline & 2.64 & 0.71 & -5.3 \\
\hline & 4.75 & 0.72 & -5.4 \\
\hline & 6.33 & 075 & -5.4 \\
\hline \multirow[t]{4}{*}{$\mathrm{K}$} & 0.47 & 0.73 & -5.3 \\
\hline & 058 & 0.77 & -5.2 \\
\hline & 0.69 & 0.82 & -5.0 \\
\hline & 0.79 & 087 & -4.8 \\
\hline \multirow[t]{4}{*}{$\mathrm{Mg}$} & 0.41 & 0.76 & -5.5 \\
\hline & 1.37 & 0.77 & -5.4 \\
\hline & 2.48 & 074 & -5.7 \\
\hline & 353 & 077 & -5.6 \\
\hline \multirow[t]{3}{*}{$\mathrm{Sr}$} & 4.52 & 074 & -7.4 \\
\hline & 8.90 & 071 & -7.6 \\
\hline & 13.82 & 0.75 & -7.4 \\
\hline
\end{tabular}

The $\mathrm{k}$ value is expressed in $\mathrm{min}^{-1} . \mathrm{mg}^{-1}$.

The $\mathrm{K}$ percent solubility is low in respect to the maximum percent solubility, because the total reaction curves are very different.

The study reported here has exposed aerosol analogs to conditions similar to those encountered in clouds during their condensation phase. These results provided a first mechanistic approach to understanding aerosol dissolution in cloud droplets, and they offer a fundamental basis for modeling of the fluxes of dissolved elements, particularly trace metals, from mineral aerosols. This work also showed that the solubility is predictable in terms of the $\mathrm{pH} /$ solubility relationship, which is important to qualify and quantify the chemistry of trace metals in the atmospheric aqueous phase and so their role in models of atmospheric chemistry [see Berglund and Elding, 1995; Walcek et al., 1997, Losno, 1999]. The identification of the atmospheric mechanisms which control the trace metals input due dissolvedparticulate distributions contributes to characterizing the atmospheric fluxes in the world's oceans. Future research on the complete evaporation-condensation cycles and their incorporation in photochemical cloud models will be critical.

Acknowledgments. We acknowledge the reviewers of this paper for their useful and constructive comments. We would like to thank Franz Rietmeijer of University of New Mexico for his English assistance.

\section{References.}

Anderson, M.A., and M.M. Morel, The influence of aqueous iron chemistry on the uptake of iron by the coastal diatom Thalassiosira Weissflogii, Limnol. Oceanogr., 27, 789-813, 1982.

Bergametti, G., Apports de matière par voie atmosphérique à la Méditerranée occidentale: Aspect géochimique et météorologique, Thèse doctoral, Univ. Parıs VII, Paris, 1987.

Berglund, J., and L. I. Elding, Manganese-catalysed autoxidation of dissolved sulfur dioxide in the atmospheric aqueous phase, Atmos. Environ., 29, 1379-1391, 1995.

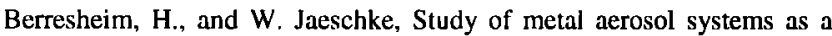
sink for atmospheric $\mathrm{SO}_{2}$, J. Atmos. Chem., 4, 31 1-334, 1986.
Betzer, P.R., et al., Long-range transport of giant mineral aerosol particles, Nature, 336, 568-571, 1988.

Boutron, C.F., C.C. Patterson, and N.I. Barkov, The occurrence of zinc in Antartic ancient 1ce and recent snow, Earth Planet. Sci. Lett., 101, 248-259, 1990.

Brady, P.V., and J.V. Walther, Controls on silicate dissolution rates in neutral and basic pH solutions at $25^{\circ} \mathrm{C}$, Geochim. Cosmochim Acta, 53, 2823-2830, 1989.

Brand, L.E., W.G Sunda, and R.R.L Guillard, Limitations of marine phytoplankton reproductive rates by zinc, manganese, and iron, Ltmnol. Oceanogr, 28, 1182-1198, 1983.

Bruno, J., I. Casas, and I. Pulgdomènech, The kinetics of dissolution of $\mathrm{UO}_{2}$ under reducing conditions and the influence of an oxidized surface layer $\left(\mathrm{UO}_{2+\mathrm{x}}\right)$ : Application of a continuous flow-through reactor, Geochim. Cosmochim. Acta, 55, 647-658, 1991.

Carroll-Webb, S A., and J.V. Walther, A surface complex reaction model for the $\mathrm{pH}$-dependence of corundum and knolinite dissolution rates, Geochim. Cosmochim. Acta, 52, 2609-2623, 1988.

Chou, L., and R. Wollast, Study of the weathering of albite at room temperature and pressure with a fluidized bed reactor, Geochim. Cosmochim Acta, 48, 2205-2218, 1984.

Clarke, A.G., and M. Radojevic, Oxidation of $\mathrm{SO}_{2}$ in rainwater and its role in acid rain chemistry, Atmos. Environ., 21, 1115-1123, 1987.

Colin, J.L., J.L. Jaffrezo, and J.M. Gros, Solubılty of major species in precipitation: Factors of variation, Atmos. Environ., Part A, 24, 537 544, 1990.

Coudé-Gaussen, G., P. Rognon, G Bergamettı, L. Gomes, B. Strauss, J.M. Gros, and M.N. Le Coustumer, Saharan dust over Fuerteventura Island (Canaries): Chemical and mineralogical characteristics, air mass trajectones and probable sources. J. Geophys. Res., 92, 97539771, 1987.

Coudé-Gaussen, G, P. Rognon, and M Le Coustumer, Incorporation progressive de poussières sahanennes aux limons des îles orientales, C.R. Acad Sci., Ser. II. 319, 1343-1349, 1994

De Baar, HJW, A.G.J. Buma, G Jacques, R.F. Nolting, and P.J. Tèguer, Iron and manganese effects on phytoplankton growth, Ber Polarforschung, 65, 34-43, 1989.

Duce, R.A., P.S. Liss, et al., The atmospheric input of trace species to the world ocean, Global Biogeochem. Cycles, 5, 193-259, 1991

Faust, B., and J. Hoigné, Photolysis of FellI-hydroxy complexes as sources of $\mathrm{OH}$ radicals in clouds, fog and rain, Atmos. Environ., Part A, 24, 79-89, 1990.

Flynn, C.M., Hydrolysis of inorganic iron (III) salts, Chem. Rev., 84, 3141, 1984.

Graedel, T.E., C.J. Weschler, and M.L. Mandich, Influence of transition metal complexes on atmospheric acidity, Nature, 315, 240-242, 1985.

Graedel, T.E., M.L. Mandich, and C.J. Weschler, Kinetic model studies of atmospheric droplets chemistry, 2, Homogenebus transition metal chemistry in raindrops, $J$ Geophys. Res., 91, 5205-5221, 1986.

Helgeson, H.C., W.M Murphy, and P. Aagaard, Thermodynamic and kınetic constrants on reaction rates among minerals and aqueous solutions, II, Rate constants effective surface area, and the hydrolysis of feldspar, Geochim. Cosmochim. Acta, 48, 2405-2432, 1984.

Herrmann, P., and G. Hänel, Wintertime optıcal properties of atmospheric particles and weather, Atmos. Environ., 31, 4053-4062, 1997

Hoffmann, M.R., and S.D. Boyces, Catalytic autoxidation of aqueous sulphur dioxide in relationship to atmospheric systems, Adv. Environ. Sct. Technol., 12, 147-189, 1983

Hoffmann, P., A.N. Dedik, F. Deutsch, T. Sinner, S. Weber, R. Eichler, S Sterkel, C.S Sastri, and H M. Ortner, Solubility of single chemical compounds from an atmospheric aerosol in pure water, Atmos. Environ, 17, 2777-2785, 1997.

Holdren, G.R., and R.A. Berner, Mechanism of feldspars weathering, I, Expenmental studies, Geochim. Cosmochim. Acta, 43, 1161-1171, 1979.

Holdren, G.R., and P.M Speyer, $\mathrm{pH}$ dependent changes in the rates and stoichiometry of dissolution of an alkali feldspar at room temperature, Am. J. Sci., 285, 994-1026, 1985.

Jacob, D.J., E.W. Gottlieb, and M.J. Prather, Chemistry of a polluted cloudy boundary layer, J. Geophys. Res, 94, 12975-13002, 1989.

Junge, C.E., The modification of aerosol size distribution in the atmosphere, final technical report, Contract Da 91-59I-EVC 2979, U.S. Army, San Diego, 1964. 
Junge, C., The importance of mineral dust as an atmosphenc constituent, in Saharan Dust: Mobilization. Transport, Deposition, edited by C Morales, pp. 49-60, John Wiley, New York, 1979

Khemani, L.T., G.A. Momin, M S. Naik, P.S. Rao, and P.D. Safai, Influence of alkaline particulates on the $\mathrm{pH}$ of cloud and rainwater in India, Atmos. Environ., 21, 1137-1 145, 1987.

Lagache, M., New data on the kinetics of the dissolution of alkali feldspar at $200^{\circ} \mathrm{C}$ in $\mathrm{CO}_{2}$ charged water, Geochim. Cosmochim. Acta, $40,157-161,1976$

Lantzy, R.J., and F.T. Mackenzie, Atmospheric trace metals: Global cycles and assessment of man's impact, Geochim. Cosmochim. Acta, $43,511-525,1979$.

Lasaga, A.C., Chemical kinetics of water-rock interactions, J. Geophys. Res., 89, 4009-4025, 1984.

Lim, B., and T.D. Jickells, Dissolved, particulate and acid leachable trace metal concentrations in North Atlantic precipitation collected on the Global Change Expedition, Global Birgerochem. Cycles, 4, 445-458, 1990.

Losno R., Trace metals acting as catalysts in a marine cloud: A box model study, Phys Chem Earth, 24, 281-286, 1999.

Losno, R., G. Bergametti, and P. Buart-Ménard, Zinc partitioning in Mediterranean rainwater. Geophys. Res. Lett., 15, 1389-1392, 1988.

Losno, R., G. Bergametti, P. Carlier, and G. Mouvier, Major ions in marine rainwater with attention to sources if alkaline and acidic species, Atmos. Environ., Part A, 25, 763-770, 1991.

Lowe, J.A., M.H. Smith, B.M. Davison, S E. Benson, M.K. Hill, C.D. O'Dowd, R.M. Harrison, and C.N. Hewitt, Physicochemical properties of atmospheric aerosol at South Uist, Atmos. Environ., 30, 3765$3776,1996$.

Luce, R.W., R.W. Bartlett, and G.A. Parks, Dissolution kinetics of magnesium silicates, Geochim. Cosmochim. Acta, 36, 35-50, 1972.

Maring, H.B., and R.A. Duce, The impact of atmospheric aerosols on trace metal chemistry in open ocean surface seawater, 1, Aluminium, Earth Planet. Sci. Lett., 84, 281-392, 1987.

Martin, J.H., and S.E. Fitzwater, Iron defiency phytoplankton growth in the north-east Pacific subarctic, Nature, 33J, 341-343, 1988.

Martin J.H., et al., Testing the iron hypothesis in ecosystem of the equatorial Pacific ocean, Nature, 371, 123-129, 1994.

Mast, M.A., and J.I. Drever, The effect of oxalate on the dissolution rates of oligoclase and tremolite, Geochim. Cosmochim. Acta, 51, 2559$2568,1987$.

Nriagu, J.O., and J.M. Pacyna, Quantitatuve assessment of worldwide contamination of air, water and soils by trace metals, Nature, 333, 134-199, 1988.

Paces, T., Steady-state kinetics and equilibrium between ground water and granitic rock, Geochim. Cosmochem. Acta, 37, 2641-2663, 1973

Patterson, C.C., and D.M. Settle, Review of data on eolian fluxes of industrial and natural lead to the lands and seas in remote regions on a global scale, Mar. Chem., 22, 137-162, 1987.

Petrovich, R., Kinetics of dissolution of mechanically comminuted rockforming oxides and silicates, II, Deformation and dissolution of oxides and silicates in the laboratory and at Earth's surface, Geochim Cosmochim. Acta, 45, 1675-1686, 1981.

Prospero, J.M., R.T. Nees, and M. Uematsu, Deposition rate of dissolved and particulate aluminium denved from Saharan dust in precipitation at Miami, Florida, J. Geophys. Res., 92, 14723-14731, 1987.

Pye, K., Loess, in Eolian Dust and Dust Deposits, pp. 198-265, Academic,San Diego, Calif., 1987.

Rich, H.W., and F.M.M. Morel, Availability of well-defined iron colloids to the marine diatom Thalasiosira Weissflogii, Limnol. Oceanogr., $35,652-662,1990$.

Rognon, R., G. Coudé-Gaussen, M. Revel, F.E. Grousset, and P. Pedemay, Holocene saharan dust deposition on the Cape Verde Islands: Sedimentological and $\mathrm{Nd}-\mathrm{Sr}$ isotopic evidence, Sedimentology, 43, 359-366, 1996.

Römer, F.G, J W. Viljeer, L. Van Den Beld, H.J. Slangewal, A.A. Veldkamp, and H.F.R. Reijnders, The chemical composition of cloud and rainwater. Results of preliminary measurements from an aircraft, Atmos. Environ., 19, 1847-1858, 1985

Schnoor, J.L., Kinetics of chemical weathering: A comparison of laboratory and field weathering rates, in Aquatic Chemical Kinetics, edited by $\mathrm{W}$ Stumm, pp 475-504, Wiley-Interscience, New York, 1990.

Schott, J., R.A. Berner, and E. Lennart Sjöberg, Mechanism of pyroxene and amphibole weathering, I, Experimental studies of iron-free minerals, Geochum. Cosmochim Acta, 45, 2123-2135, 1981

Slınn, W.G.N., Air-to-sea transfer of particles, in Air-Sea Exchange of Gases and Particles, NATO ASI Ser., edited by P.S. Liss and W G.N. Slinn, pp. 299-405, D. Reidel, Norwell, Mass., 1983.

Smith, S.V., and F.T. Mackenzie, Comments on the role of oceanic biota as a sink for anthropogenic $\mathrm{CO}_{2}$ emissions, Global Biogeochem. Cycles, 5, 189-190, 1991.

Spokes, L.J., and T.D. Jickells, Factors controlling the solubility of aerosol trace metals in the atmosphere and on mixing into seawater, Aquat. Geochem., I, 355-374, 1996.

Spokes, L.J., T D. Jickells, and B. Lim, Solubilisation of aerosol trace metals by cloud processing A laboratory study, Gerchim. Cosmochim Acta, 58, 3281-3287, 1994.

Statham, P.J., and R. Chester, Dissolution of manganese from marıne atmospheric particulates into seawater and rainwater, Geochim Cosmochim. Acta, 52, 2433-2437, 1988.

Stumm, W., and G. Furrer, The dissolution of oxides and aluminium silicates; Examples of surface-coordination-controlled kinetics, in Aquatlc Surface Chemistry, edited by Werner Stumm, pp. 197-220, Wiley-Interscience, New York, 1987

Stumm, W., and J.J. Morgan, Kinetics at the solid-water interface: Adsorption, dissolution of minerals, nucleation, and crystal growth, in Aquatic Chemistry, ${ }^{\text {rd }}$ rd., edited by J.L. Schnoor and A. Zehnder, pp. 760-817, Wiley-Interscience, New York, 1996.

Stumm, W., and R. Wollast, Coordination chemistry of weathering: Kinetics of the surface-controlled dissolution of oxides minerals, $R e v$ Geophys, 28, 53-69, 1990

Sunda, W.G., R.T. Barber, and S.A. Huntsman, Phytoplankton growth in nutrient rich seawater: Importance of copper-manganese cellular interactions, J. Mar., Res., 39, 567-586, 1981.

Tole, M.P., A.C. Lasaga, C. Pantano, and W.B. White, The kinetics of dissolution of nepheline $\left(\mathrm{NaAlSiO}_{4}\right)$, Geochım. Cosmochim. Acta, 50, 379-392, 1986.

Turner, D.R., M. Whitfield, and A.G. Dickson, The equilibrium speciation of dissolved components in freshwater and seawater at $25^{\circ} \mathrm{C}$ and $1 \mathrm{~atm}$ pressure, Geochim. Cosmochim. Acta, 45, 855-881, 1981.

Walcek, C.J., H.H. Yuan, and W.R. Stockwell, The influence of aqueousphase chemical reactions on ozone formation in polluted and nonpolluted clouds, Atmos. Environ., 31, 1221-1237, 1997.

Warneck, P., Chemistry of the Natural Atmosphere, Acadernic, San Diego, Calif., 1989.

Weschler, C.J., M.L. Mandich, and T.E. Graedel, Speciation, photosensitıvity, and reaction of transition metal ions in atmospheric droplets, J. Geophys. Res., 91, 5189-5204, 1986.

Williams, P.T., M. Radojevic, and A.G. Clarke, Dissolution of trace metals from particles of industrial origin and its influence on the composition of rainwater, Atmos. Environ., 22, 1433-1442, 1988.

Wollast, R., Kinetics of the alteration of K-feldspar in buffered solution at low temperature, Geochim. Cosmochim. Acta, 31, 635-648, 1967.

Wollast, R., and L. Chou, Kinetic study of dissolution of albite with a continuous flow-through fluidized bed reactor, in The Chemistry of Weathering, edited by Drever J.I., pp. 75-96, D. Reidel, Norwell, Mass., 1985.

Zhu, X., J.M. Prospero, F.J. Millero, D.L. Savoie, and G.W. Brass, The solubility of ferric ion in marine mineral aerosol solutions at ambient relative humidities, Mar. Chem., 38, 91-107, 1992.

Zhu, X., J.M. Prospero, and F.J. Millero, Diel variability of soluble Fe(II) and soluble total $\mathrm{Fe}$ in North African dust in the trade winds at Barbados, J. Geophys. Res., 102, 21297-21305, 1997.

Zhuang, G., Z. Yi, R.A. Duce, and P.R. Brown, Link between iron and sulphur cycles suggested by detection of $\mathrm{Fe}$ (II) in remote marine aerosols, Nature, 355, 537-539, 1992.

S. Cholbi, K.V. Desboeufs, R. Losno, F. Vimeux, Laboratoire Interuniversitaire des Systèmes Atmosphériques, Universités Paris 7 et 12, UMR CNRS 7583, Créteil, France. (desboeufs@lisa.univ-pans 12.fr; losno@ lisa.univ-paris 12.fr)

(Received November 19, 1998; revised April 6, 1999; accepted April 7, 1999.) 